\title{
CTX-M-14 Producing Enterobacteriaceae Isolated from Chickens at Gyeongsang Provinces
}

\author{
Ji Youn Sung and Taek Young Kwon \\ Department of Biomedical Laboratory Science, Far East University, Eumseong 27601, Korea
}

\section{경북지역의 닭으로부터 CTX-M-14 생성 장내세균 분리동정}

\author{
성지연, 권택영 \\ 극동대학교 임상병리학과
}

\begin{abstract}
Antimicrobial agents have been used in poultry for treatment of bacterial infections or additives over the past half century. However, increasing antimicrobial resistance has led to selective pressure for therapeutic use in humans and made treatment of bacterial infection more difficult. In this study, we examined the prevalence of plasmid mediated antimicrobial resistant determinants for resistance to $\beta$-lactam, quinolone, and aminoglycoside in Enterobacteriaceae isolates obtained from chickens in Gyeongsang provinces, and correlation between the resistant genes and antimicrobial resistance rate was also assessed. A total of 43 Enterobacteriaceae isolates were recovered from 40 chickens at Gyeongsang provinces in Korea. Antimicrobial susceptibility was determined by disk diffusion method. PCR and DNA sequencing were performed to characterize the antimicrobial resistant genes. Of the 43 Enterobacteriaceae isolates tested, 2 isolates harbored blactX-M-14 gene, and 2 and 5 strains contained $q n r S$ and $a a c\left(6^{\prime}\right)-1 b-c r g e n e s$, respectively. A total of 43 isolates displayed a relatively lower susceptible rate ranging between 0.0 and $23.3 \%$ to most of the antimicrobial agents, except cefepime, ceftazidime, and cefaclor. We confirmed that plasmid mediated antimicrobial resistant determinants were distributed in Enterobacteriaceae isolates from chickens. Investigation of the genes and monitoring of antimicrobial resistance rate is required to prevent further spreading of antimicrobial resistant genes among Enterobacteriaceae isolates.
\end{abstract}

Keywords: Chicken, Plasmid, Antimicrobial resistant determinants, Enterobacteriaceae

This is an Open Access article distributed under the terms of the Creative Commons Attribution Non-Commercial License (http://creativecommons.org/licenses/by-nc/4.0) which permits unrestricted non-commercial use, distribution, and reproduction in any medium, provided the original work is properly cited.

Copyright @ 2016 The Korean Society for Clinical Laboratory Science. All rights reserved.
Corresponding author: ji Youn Sung Department of Biomedical Laboratory Science, Far East University, 76-32 Daehak-gil, Gamgok-myeon, Eumseong 27601, Korea Tel: 82-43-879-3668 Fax: 82-43-880-3876 E-mail: azaza72@naver.com

Received: April 29, 2016 Revised: May 10, 2016 Accepted: May 11, 2016

\section{서 론}

항균제는 세균감염을 치료하기 위한 목적으로 사람과 동물에 광 범위하게 사용되어 왔으며, 가축의 성장촉진을 위한 목적으로 사료 에 첨가되기도 했다. 그러나 항균제의 무분별한 사용으로 다양한 항균제에 동시에 내성을 나타내는 다제내성 세균의 출현이 빈번해 지고 있다. 이러한 다제내성 세균은 다양한 종류의 항균제를 사용 하는 병원에 국한되지 않고 지역사회에도 빈번하게 출현하고 있으
며 특히 사람과 동물의 장에 존재하는 정상균무리에도 포함되어 있 는 경우가 종종 보고되고 있다[1,2]. 국내에서도 가축으로부터 분 리된 세균들이 다양한 항균제에 높은 내성률을 나타낼 뿐 아니라 다제내성을 보이는 경우가 빈번하다고 한다[3]. 가축의 경우 최근 까지도 다량의 항균제가 사료에 첨가되었는데 특별한 제약이 없었 기 때문에 가축에 존재하는 정상균무리 중에는 항균제 내성 세균이 다수 포함되어 있을 것으로 추정된다. 가축에 출현한 항균제 내성 세균은 분변을 통해 토양, 지하수, 및 하천 등으로 확산 되거나, 식 
용을 위해 가공되는 과정에서 더 많은 내성세균의 출현을 유도 할 수 있다. 이렇게 발생한 내성세균들은 다양한 경로를 통해 사람의 장에 존재하는 정상균무리에 내성유전자를 전달할 수 있어 또 하나 의 내성세균 확산 경로가 되고 있다[3].

Extended-spectrum $\beta$-lactamase (ESBL)은 염색체 혹은 플라 스미드에 그 유전자가 존재하며 penicillin, cephalosporin, 및 monobactam 계열의 항균제에 세균이 내성을 갖도록 해준다. $\mathrm{ESBL}$ 을 생성하는 세균은 $\beta$-lactam 계열의 항균제 외에도 aminoglycoside 및 trimethoprim-sulfamethoxasole 계열의 항균제에 내성을 나타내는 경우가 많아감염환자를 치료하기 위한 항균제 선 택에 많은 어려움을 주고 있다. ESBL을 생성하는 세균은 비단 사람 의 경우에만 국한 된 것이 아니고 전세계적으로 동물 및 생태계에 확산되고 있어 내성세균의 확산이란 점에서 많은 우려를 낳고 있다 [4]. 장내세균에서 분리되는 주된 ESBL형은 1990년대 후반 까지만 해도 TEM-52, SHV-12, 및 SHV-2a형이었으나 최근 들어 CTX-M 형이 주로 분리되고 있고 국내에서도 CTX-M-14 및 CTX-M-15 형이 가장 빈번하게 분리가 되고 있다고 보고되고 있다[5].

한편 ESBL을 생성하는 장내세균은 플라스미드를 통해 ESBL 유 전자를 다른 세균으로 전파하기도 하는데 이때 내성유전자를 전달 받은 세균은 $\mathrm{ESBL}$ 항균제에 내성을 나타내게 된다. 게다가 플라스 미드를 통해 운반될 수 있는 quinolone 내성에 관여하는 $q n r$ 및 aac (6')-Ib-cr 유전자와 aminoglycoside 계열의 항균제 내성에 관여하는 $a r m A$ 및 $r m t$ 유전자를 동시에 획득할 경우 세균은 다제 내성을 나타내게 된다[6,7]. 플라스미드를 매개로 한 항균제 내성 유전자의 수평적 확산은 다제내성 세균을 출현시키고 빠르게 확산 시킬 수 있어 지속적인 감시가 필요하다.

본 연구에서는 경북지역에서 사육된 닭으로부터 분리된 장내세 균을 대상으로 $\mathrm{ESBL}$ 의 생성여부를 확인하였고 그 유전형을 조사하 였다. 아울러 플라스미드를 통해 전파될 수 있는 quinolone 내성유 전자( $q n r$ 및 $\left.a a d\left(6^{\prime}\right)-I b-c r\right)$ 와 aminoglycoside 내성유전자 $(\mathrm{armA}$ 및 $\mathrm{rm} t)$ 의 빈도를 조사하고 내성유전자의 종류를 확인하여 축사환경에 확산되어 있는 항균제 내성유전자를 파악하였다. 이 결 과는 축사환경에서 다제내성 세균의 출현 및 전파양상을 숙고하고 확산 방지책을 마련하는데 필요한 기초자료가 될 것으로 사료된다.

\section{재료 및 방법}

\section{1. 균주의 수집}

2013년 8월 12일부터 9월 30일까지 경북지역 일 개의 양계장에 서 수집된 닭의 맹장으로부터 분리된 균주를 대상으로 하였다. 분 리된 균주는 Vitek GNI card (bioMerieux Vitek Inc.,
Hazelwood, MO, USA)를 이용하여 동정하였다.

\section{2. 항균제 감수성 시험}

미국의 Clinical and Laboratory Standards Institute (CLSI) 지 침에 따라 amikacin, ampicillin, cefaclor, cefepime, cefotaxime, ceftazidime, cephalothin, ciprofloxacin, gentamicin, kanamycin, levofloxacin, nalidixic acid, spectinomycin, streptomycin (Oxoid, Basingstoke, UnitedKingdom)에 대한 감수성 을 Mueller-Hinton 한천(Difco, Cockeysville, MD, USA)을 사용 하여 디스크 확산법으로 확인하였다[8]. 정도관리를 위해서 Escherichia coli ATCC 25922를 동시에 시험하여 허용범위내에 있는지를 확인하였다.

\section{ESBL 생성 확인시험}

CLSI 디스크 확산법에 의한 ESBL 생성 확인시험을 시행하였다 [8]. Mueller-Hinton (MH) 한천 배지(BBL MicrobiologySystems, Cockeysville, $\mathrm{MD}$, USA)에 McFarland 0.5 탁도의 균액을 바른 후 cefotaxime (BBL, $30 \mu \mathrm{g}$ )과 cefotaxime/clavulanic acid (CTC) (BBL, 30/10 $\mu \mathrm{g}$ ), ceftazidime (BBL, $30 \mu \mathrm{g}$ )과 ceftazidime/clavulanic acid $(\mathrm{CZC})(\mathrm{BBL}, 30 / 10 \mu \mathrm{g})$ 디스크를 놓고 $35^{\circ} \mathrm{C}$ 에서 16 18시간 배양 후 억제대를 측정하여 CTC 또는 CZC에 의한 억 제대가 cefotaxime과 ceftazidime에 의한 억제대 보다 $5 \mathrm{~mm}$ 이 상 클 경우 $\mathrm{ESBL}$ 생성 양성 균주로 판정하였다.

\section{4. 항균제 내성유전자 검출}

플라스미드를 매개로 하여 운반되는 항균제 내성유전자를 검출 하기 위해 본 연구에서 수집된 총 48균주를 대상으로 기존의 시발 체(Table 1)를 사용하여 중합효소연쇄반응을 수행하였다[9-12]. 단 ESBL 유전자의 유전형 확인을 위한 중합효소연쇄반응은 ESBL 생성확인 시험에서 양성을 보인 균주를 대상으로 하였다. 대상 균 주를 brain heart infusion broth (Difco)에 접종하여 $37^{\circ} \mathrm{C}$ 에서 하 룻밤 진탕배양 한 후 배양액으로부터 DNA 추출시약(솔젠트, 대전, 한국)을 사용하여 chromosomal DNA를 추출하였다. DNA 추출 액(5 mL), 10× Taq buffer ( $2.5 \mathrm{~mL}), 10 \mathrm{mM}$ dNTP mix $(0.5 \mathrm{~mL})$, primer 각 $10 \mathrm{pmol}, 0.7 \mathrm{U} \mathrm{Taq} \mathrm{DNA}$ 중합효소(솔젠트) 및 증류수를 혼합하여 총 부피 $25 \mathrm{~mL}$ 의 반응용액을 만들었다. Gene Amp PCR System 9600 (Perkin-Elmer Centus Corp.)으로 $95^{\circ} \mathrm{C}$ 에서 5 분간 반응시킨 후, $95^{\circ} \mathrm{C}$ 에서 20 초, $59^{\circ} \mathrm{C}$ 에서 40 초, $72^{\circ} \mathrm{C}$ 에서 30 초씩 30 회 증폭 반응시키고, $72^{\circ} \mathrm{C}$ 에서 5 분간 연장 반응시켰다. 각각의 PCR 생산물을 ethidium bromide가 포함된 1\% agarose gel에서 40 분간 전기영동하여 band를 확인하였다. 증폭산물을 DNA 추출 
Table 1. Oligonucleotides used in this study for detection of plasmid mediated antimicrobial resistant genes

\begin{tabular}{|c|c|c|c|c|}
\hline Reaction number & Primer & Sequence $\left(5^{\prime}-3^{\prime}\right)$ & Gene & Reference \\
\hline \multirow[t]{12}{*}{ ESBL genes } & TEM-F & ATAAAATTCTTGAAGACGAAA & blatem & [9] \\
\hline & TEM-R & GACAGTTACCAATGCTTAATCA & & \\
\hline & SHV-F & GGGTTATTCTTATTTGTCGC & blashv & [9] \\
\hline & SHV-R & TTAGCGTTGCCAGTGCTC & & \\
\hline & $\mathrm{CTX}-\mathrm{M}-1 \mathrm{~F}$ & GACGATGTCACTGGCTGAGC & blactX-M1-like & [9] \\
\hline & $C T X-M-1 R$ & AGCCGCCGACGCTAATACA & & \\
\hline & $\mathrm{CTX}-\mathrm{M}-2 \mathrm{~F}$ & GCGACCTGGTTAACTACAATCC & blactX-м2-like & [9] \\
\hline & $C T X-M-2 R$ & CGGTAGTATTGCCCTTAAGCC & & \\
\hline & $\mathrm{CTX}-\mathrm{M}-8 \mathrm{~F}$ & AGACCTGATTAACTACAATCCCATTA & blactX-м8-like & [9] \\
\hline & $C T X-M-8 R$ & ACTTTCTGCCTTCTGCTCTGGC & & \\
\hline & $C T X-M-9 F$ & GCTGGAGAAAAGCAGCGGAG & blactX-м9-like & [9] \\
\hline & CTX-M-9R & GTAAGCTGACGCAACGTCTG & & \\
\hline \multirow{14}{*}{$\begin{array}{l}\text { Aminoglycoside } \\
\text { resistant genes }\end{array}$} & $\operatorname{armA}-\mathrm{F}$ & CAAATGGATAAGAATGATGTT & $\operatorname{arm} A$ & [10] \\
\hline & $\operatorname{armA-R}$ & TTATTTCTGAAATCCACT & & \\
\hline & $r m t A-F$ & ATGAGCTTTGACGATGCCCTA & $r m t A$ & [10] \\
\hline & $r m t A-R$ & TCACTTATTCCTTTTTATCATG & & \\
\hline & $r m t B-F$ & ATGAACATCAACGATGCCCT & $r m t B$ & [10] \\
\hline & $r m t B-R$ & CCTTCTGATTGGCTTATCCA & & \\
\hline & $\mathrm{rmtC}-\mathrm{F}$ & CGAAGAAGTAACAGCCAAAG & $r m t C$ & [10] \\
\hline & $\mathrm{rmtC}-\mathrm{R}$ & ATCCCAACATCTCTCCCACT & & \\
\hline & $r m t D-F$ & CGGCACGCGATTGGGAAGC & $r m t D$ & {$[10]$} \\
\hline & $r m t D-R$ & CGGAAACGATGCGACGAT & & \\
\hline & $r m t E-F$ & ATGAATATTGATGAAATGGTTGC & $r m t E$ & {$[10]$} \\
\hline & $r m t E-R$ & TGATTGATTTCCTCCGTTTTTG & & \\
\hline & $\mathrm{rmtF}-\mathrm{F}$ & GCGATACAGAAAACCGAAGG & $r m t F$ & {$[10]$} \\
\hline & $r m t F-R$ & ACCAGTCGGCATAGTGCTTT & & \\
\hline \multirow{8}{*}{$\begin{array}{l}\text { Quinolone resistant } \\
\text { genes }\end{array}$} & QnrA-F & AGAGGATTTCTCACGCCAGG & qnrA1 to qnrA6 & {$[11]$} \\
\hline & QnrA-R & TGCCAGGCACAGATCTTGAC & & \\
\hline & QnrB-F & GGMATHGAAATTCGCCACTG & qnrB1 to $q n r B 6$ & [11] \\
\hline & QnrB-R & TTTGCYGYYCGCCAGTCGAA- & & \\
\hline & QnrS-F & GCAAGTTCATTGAACAGGGT & qnrS1 to qnrS2 & {$[11]$} \\
\hline & Qnrs-R & TCTAAACCGTCGAGTTCGGCG & & \\
\hline & $A A C\left(6^{\prime}\right)-I b F$ & TGACCAACAGCAACGATTCC & $\operatorname{aac}\left(6^{\prime}\right)-1 b$ & [12] \\
\hline & $A A C\left(6^{\prime}\right)-I b R$ & TTAGGCATCACTGCGTGTTC & & \\
\hline
\end{tabular}

Abbreviation: $F$, sense primer; $R$, antisense primer.

시약(솔젠트)로 분리 후, BigDye Terminator Cycle Sequencing Kit (PE Applied Biosystems, Foster City, CA, USA)와 ABI PRISM 3730xl DNA analyzer (PE Applied Biosystems)를 이용하여 염기 서열을 분석하였다.

\section{결 과}

\section{1. 항균제 감수성 양상}

장내세균과에 속하는 총 43 균주가 경북지역의 일 개의 양계장 에서 수집된 40 마리의 닭의 맹장으로부터 분리되었다. 가장 많이 분리된 균종은 E. coli $(\mathrm{n}=32)$ 였으며, Proteus mirabilis $(\mathrm{n}=4)$ 및 Proteus penneri $(\mathrm{n}=4)$ 가 그 다음으로 많이 분리되었다. Cronobacterspp.와 Shigella dysenteriae도 각각 2균주와 1균주씩 분리 되었다. 이들 43 균주를 대상으로 항균제 감수성 시험을 한 결과 cefepime에 대한 감수성이 $97.7 \%$ 로 가장 높았으며 ceftazidime (72.1\%)과 cefaclor (67.4\%)가 그 다음으로 높았다. 한편 이상의 3 가지 cephalosporin계열 항균제를 제외한 11 가지의 항균제에 대 해서는 모두 $30 \%$ 미만의 낮은 감수성률을 보였다(Table 2).

\section{2. 분자생물학적인 방법에 의한 항균제 내성 유전자 검출}

CLSI 디스크 확산법에 의한 ESBL 생성 확인시험에서 양성 결과 를 보인 8균주를 대상으로 Ambler class A에 속하는 ESBL (blatEM, bla $a_{\mathrm{SHV}}$, bla $a_{\mathrm{CTX}-\mathrm{M}}$ )유전자 검출을 위해 중합효소연쇄반응을 실시한 결과 blacTX-M-14에 대해 2균주가 양성반응을 보였다. 유전자의 유 전형을 결정하기 위해 염기서열분석을 실시한 결과 2균주 모두 CTX-M-14형으로 확인되었다(Table 3).

한편 총 43균주를 대상으로 quinolone 내성유전자 $(q n r$ 및 $\left.\operatorname{aac}\left(6^{\prime}\right)-I b-c r\right)$ 및 aminoglycoside 내성유전자 $(a r m A$ 및 $r m t)$ 의 
Table 2. Antimicrobial susceptibilities to 14 antimicrobial agents of Enterobacteriaceae isolates from chicken cecum

\begin{tabular}{|c|c|c|c|c|c|c|c|c|c|c|c|c|c|c|c|}
\hline \multirow{2}{*}{ Isolates } & \multirow{2}{*}{ Species } & \multicolumn{14}{|c|}{ Antimicrobial susceptibility } \\
\hline & & CTX & KF & K & AMP & NA & $S$ & $\mathrm{SH}$ & AK & CAZ & CEC & CIP & FP & $\mathrm{CN}$ & LEV \\
\hline A8 & E. coli & $\mathrm{R}$ & $\mathrm{R}$ & $\mathrm{R}$ & $\mathrm{R}$ & $\mathrm{R}$ & $\mathrm{R}$ & $\mathrm{R}$ & । & $\mathrm{S}$ & $\mathrm{S}$ & $\mathrm{R}$ & $\mathrm{S}$ & $\mathrm{R}$ & $\mathrm{R}$ \\
\hline A9 & E. coli & $\mathrm{R}$ & $\mathrm{R}$ & $\mathrm{R}$ & $\mathrm{R}$ & $\mathrm{R}$ & $\mathrm{R}$ & । & $\mathrm{R}$ & $S$ & I & $\mathrm{R}$ & $\mathrm{S}$ & । & $\mathrm{R}$ \\
\hline A16 & E. coli & $\mathrm{R}$ & $\mathrm{R}$ & $\mathrm{R}$ & $\mathrm{R}$ & $\mathrm{R}$ & $\mathrm{R}$ & $\mathrm{R}$ & $\mathrm{R}$ & $S$ & । & $\mathrm{R}$ & $S$ & $\mathrm{R}$ & $\mathrm{R}$ \\
\hline A22 & E. coli & $\mathrm{R}$ & $\mathrm{R}$ & $R$ & $R$ & $R$ & $R$ & $R$ & $R$ & $\mathrm{~S}$ & $S$ & $R$ & $\mathrm{~S}$ & 1 & $R$ \\
\hline A24 & E. coli & I & $\mathrm{R}$ & $R$ & $R$ & $R$ & $\mathrm{R}$ & I & 1 & $S$ & $S$ & $R$ & $S$ & I & $\mathrm{R}$ \\
\hline A31 & E. coli & I & I & $\mathrm{R}$ & I & $\mathrm{R}$ & I & $\mathrm{R}$ & $\mathrm{R}$ & $S$ & $S$ & $\mathrm{R}$ & $S$ & I & $\mathrm{R}$ \\
\hline A33 & E. coli & $\mathrm{R}$ & $\mathrm{R}$ & $\mathrm{R}$ & $\mathrm{R}$ & $\mathrm{R}$ & I & $S$ & S & $S$ & $\mathrm{R}$ & $\mathrm{R}$ & $S$ & $\mathrm{R}$ & $\mathrm{R}$ \\
\hline A36W & E. coli & I & $\mathrm{R}$ & $\mathrm{R}$ & 1 & $\mathrm{R}$ & $S$ & $R$ & 1 & $S$ & $S$ & $\mathrm{R}$ & $S$ & I & $\mathrm{R}$ \\
\hline A37 & E. coli & $\mathrm{R}$ & $\mathrm{R}$ & $\mathrm{R}$ & $\mathrm{R}$ & $\mathrm{R}$ & $\mathrm{R}$ & $\mathrm{R}$ & I & $S$ & 1 & $\mathrm{R}$ & $S$ & I & $\mathrm{R}$ \\
\hline A39 & E. coli & $\mathrm{S}$ & I & I & $\mathrm{R}$ & $R$ & $R$ & $\mathrm{R}$ & $R$ & $S$ & $S$ & $R$ & $\mathrm{~S}$ & I & $\mathrm{R}$ \\
\hline A41W & E. coli & $\mathrm{R}$ & $\mathrm{R}$ & $R$ & $\mathrm{R}$ & $R$ & $\mathrm{R}$ & I & I & $S$ & $S$ & $R$ & $S$ & 1 & $\mathrm{R}$ \\
\hline $\mathrm{A} 42 \mathrm{~W}$ & E. coli & $R$ & $\mathrm{R}$ & $R$ & $\mathrm{R}$ & $R$ & $\mathrm{R}$ & $R$ & $R$ & $S$ & I & $R$ & $S$ & I & $\mathrm{R}$ \\
\hline A60W & E. coli & $\mathrm{R}$ & $\mathrm{R}$ & I & $\mathrm{R}$ & $\mathrm{R}$ & $\mathrm{R}$ & $\mathrm{R}$ & I & I & 1 & I & $S$ & I & S \\
\hline $\mathrm{A} 61 \mathrm{~W}$ & E. coli & $\mathrm{R}$ & $\mathrm{R}$ & $\mathrm{R}$ & $\mathrm{R}$ & $\mathrm{R}$ & $\mathrm{R}$ & $\mathrm{R}$ & 1 & I & 1 & $\mathrm{R}$ & $S$ & I & $\mathrm{R}$ \\
\hline A63 & E. coli & I & $R$ & $R$ & $R$ & $R$ & $R$ & $\mathrm{R}$ & I & $S$ & I & $R$ & $\mathrm{~S}$ & 1 & $R$ \\
\hline B1 & E. coli & $\mathrm{R}$ & $\mathrm{R}$ & $\mathrm{R}$ & $\mathrm{R}$ & $\mathrm{R}$ & $\mathrm{R}$ & $\mathrm{R}$ & 1 & $S$ & $S$ & $\mathrm{R}$ & $S$ & $\mathrm{R}$ & $\mathrm{R}$ \\
\hline B2W & E. coli & $\mathrm{R}$ & 1 & $\mathrm{R}$ & $\mathrm{R}$ & $R$ & $S$ & $\mathrm{R}$ & I & I & $S$ & I & $S$ & 1 & $S$ \\
\hline B6 & E. coli & I & $\mathrm{R}$ & $R$ & $\mathrm{R}$ & $R$ & $R$ & $\mathrm{R}$ & $R$ & S & $\mathrm{S}$ & $R$ & $\mathrm{~S}$ & i & $R$ \\
\hline B6W & E. coli & $S$ & $S$ & $\mathrm{R}$ & $\mathrm{R}$ & $\mathrm{R}$ & $\mathrm{R}$ & $R$ & I & $S$ & $S$ & $\mathrm{R}$ & $S$ & $S$ & $\mathrm{R}$ \\
\hline B9 & E. coli & $S$ & $\mathrm{R}$ & $R$ & I & $R$ & I & $R$ & S & $S$ & $\mathrm{~S}$ & I & $\mathrm{S}$ & $\mathrm{R}$ & S \\
\hline B17 & E. coli & $\mathrm{R}$ & I & $R$ & I & $R$ & $R$ & $\mathrm{R}$ & I & I & $\mathrm{S}$ & $R$ & $\mathrm{~S}$ & 1 & $\mathrm{R}$ \\
\hline B22W & E. coli & I & $S$ & $\mathrm{R}$ & $\mathrm{R}$ & $R$ & $S$ & $\mathrm{R}$ & 1 & $S$ & $S$ & 1 & $S$ & I & I \\
\hline B26 & E. coli & I & $\mathrm{R}$ & $\mathrm{S}$ & $\mathrm{R}$ & $R$ & $R$ & $R$ & $R$ & I & 1 & $R$ & $\mathrm{~S}$ & $\mathrm{R}$ & I \\
\hline B29W & E. coli & $\mathrm{R}$ & $R$ & $R$ & $R$ & $R$ & 1 & $R$ & 1 & $S$ & $S$ & I & $S$ & 1 & $S$ \\
\hline B32W & E. coli & S & $S$ & $R$ & $R$ & $R$ & $R$ & $R$ & I & S & $S$ & $R$ & $\mathrm{~S}$ & I & $R$ \\
\hline B33 & E. coli & I & $R$ & $R$ & I & $R$ & $\mathrm{R}$ & $R$ & $R$ & I & $\mathrm{S}$ & $R$ & $S$ & I & $R$ \\
\hline B53 & E. coli & I & 1 & I & $S$ & $\mathrm{R}$ & I & $\mathrm{R}$ & $\mathrm{R}$ & $S$ & $S$ & $\mathrm{R}$ & $S$ & 1 & $\mathrm{R}$ \\
\hline B55 & E. coli & $R$ & $\mathrm{R}$ & $R$ & $\mathrm{R}$ & $R$ & $R$ & $\mathrm{R}$ & $\mathrm{R}$ & $\mathrm{S}$ & $S$ & S & $S$ & S & $R$ \\
\hline B56 & E. coli & $\mathrm{R}$ & $\mathrm{R}$ & $\mathrm{R}$ & $\mathrm{R}$ & $\mathrm{R}$ & $\mathrm{R}$ & $\mathrm{R}$ & $\mathrm{R}$ & $S$ & I & $\mathrm{R}$ & $S$ & S & $\mathrm{R}$ \\
\hline B60 & E. coli & $\mathrm{R}$ & $\mathrm{R}$ & $R$ & $\mathrm{R}$ & $R$ & $\mathrm{R}$ & $R$ & $\mathrm{R}$ & $S$ & I & $\mathrm{R}$ & $S$ & I & $\mathrm{R}$ \\
\hline B70 & E. coli & $\mathrm{S}$ & $R$ & $R$ & $R$ & $R$ & $R$ & $R$ & $R$ & $\mathrm{~S}$ & $S$ & $R$ & $\mathrm{~S}$ & $S$ & $R$ \\
\hline B72 & E. coli & 1 & $\mathrm{R}$ & I & $\mathrm{R}$ & $\mathrm{R}$ & $R$ & $\mathrm{R}$ & $\mathrm{R}$ & $S$ & I & $R$ & $S$ & 1 & $\mathrm{R}$ \\
\hline B14W & P. mirabilis & I & $\mathrm{R}$ & $R$ & $\mathrm{R}$ & $R$ & I & $\mathrm{R}$ & I & S & $S$ & S & $S$ & I & S \\
\hline B16W & P. mirabilis & S & $\mathrm{S}$ & $R$ & $\mathrm{R}$ & $R$ & $R$ & $\mathrm{R}$ & $R$ & I & $\mathrm{S}$ & $R$ & $\mathrm{~S}$ & I & $\mathrm{R}$ \\
\hline B37W & P. mirabilis & $\mathrm{S}$ & $S$ & $\mathrm{R}$ & $\mathrm{R}$ & $\mathrm{R}$ & $R$ & $\mathrm{R}$ & I & $S$ & $S$ & $R$ & $\mathrm{~S}$ & $\mathrm{~S}$ & $\mathrm{R}$ \\
\hline B48W & P. mirabilis & $\mathrm{R}$ & 1 & $\mathrm{R}$ & $\mathrm{R}$ & I & $\mathrm{R}$ & $R$ & I & I & $S$ & S & I & I & S \\
\hline B10W & P. penneri & $R$ & I & $R$ & $R$ & $R$ & $R$ & $\mathrm{R}$ & $R$ & i & $S$ & $\mathrm{~S}$ & $\mathrm{~S}$ & I & S \\
\hline B19W & P. penneri & $\mathrm{S}$ & 1 & $\mathrm{R}$ & $\mathrm{R}$ & $\mathrm{R}$ & $R$ & $R$ & I & $\mathrm{R}$ & $\mathrm{S}$ & $\mathrm{R}$ & $\mathrm{S}$ & 1 & $\mathrm{R}$ \\
\hline B28 & P. penneri & $\mathrm{R}$ & $\mathrm{R}$ & । & $\mathrm{R}$ & $R$ & $R$ & S & । & S & S & $R$ & $\mathrm{~S}$ & S & $R$ \\
\hline B43W & P. penneri & $\mathrm{R}$ & $S$ & $R$ & $\mathrm{R}$ & $\mathrm{R}$ & $R$ & $\mathrm{R}$ & I & $S$ & $S$ & S & $S$ & $\mathrm{~S}$ & S \\
\hline A39W & C. sakazakii & I & 1 & I & $\mathrm{R}$ & $\mathrm{R}$ & $\mathrm{R}$ & $\mathrm{R}$ & $\mathrm{R}$ & I & $\mathrm{S}$ & I & $\mathrm{S}$ & I & S \\
\hline B31 & C. sakazakii & $R$ & $\mathrm{R}$ & $\mathrm{R}$ & $\mathrm{R}$ & $R$ & $R$ & $\mathrm{R}$ & $\mathrm{R}$ & S & $\mathrm{R}$ & । & $\mathrm{S}$ & 1 & S \\
\hline \multirow{4}{*}{ B22 } & S. dysenteriae & I & $\mathrm{R}$ & $\mathrm{R}$ & $\mathrm{R}$ & $\mathrm{R}$ & $\mathrm{R}$ & $\mathrm{R}$ & I & I & I & $\mathrm{R}$ & $\mathrm{S}$ & $\mathrm{R}$ & $\mathrm{R}$ \\
\hline & (\%) of $\mathrm{S}$ & 18.6 & 14.0 & 2.3 & 2.3 & 0.0 & 7.0 & 4.7 & 4.7 & 72.1 & 67.4 & 11.6 & 97.7 & 16.3 & 23.3 \\
\hline & (\%) of I & 30.2 & 20.9 & 14.0 & 11.6 & 2.3 & 14.0 & 7.0 & 51.2 & 25.6 & 27.9 & 16.3 & 2.3 & 67.4 & 4.7 \\
\hline & (\%) of $\mathrm{R}$ & 51.2 & 65.1 & 83.7 & 86.9 & 97.7 & 79.0 & 88.4 & 44.2 & 2.3 & 4.7 & 72.1 & 0.0 & 16.3 & 72.1 \\
\hline
\end{tabular}

Abbreviation: AK, amikacin; KF, cephalothin; CTX, cefotaxime; CAZ, ceftazidime; CEC, cefaclor FP, cefepime; K, kanamycin; AMP, ampicillin; CIP, ciprofloxacin; NA, nalidixic acid; S, streptomycin; SH, spectinomycin; CN, gentamicin; LEV, levofloxacin; S, susceptible; I, intermediate resistant, $\mathrm{R}$, resistant.

빈도를 조사하기 위해 중합효소연쇄반응을 수행한 결과 aminoglycoside 내성유전자를 검출하기 위한 반응에서는 대상 균주 모 두 음성반응을 보였다. 반면 quinolone 내성유전자인 qniS 와 $\operatorname{aac}\left(6^{\prime}\right)-I b-C r$ 를 검출하기 위한 반응에서는 각각 2균주와 5균주
가 양성반응을 보였다. 양성반응을 보인 PCR 산물을 대상으로 유 전형을 결정하기 위해 염기서열분석을 실시한 결과 $q n \pi 5$ 와 $a a c\left(6^{\prime}\right)-I b-c r$ 유전자 증폭산물은 각각 $q n r S$ 와 $a a c\left(6^{\prime}\right)-I b-c r$ 유 전자로 확인되었다. 본 연구에서는 $q n r A$ 및 $q n r B$ 유전자는 검출되지 
Table 3. Antimicrobial resistant determinants in Enterobacteriaceae isolates from chicken cecum

\begin{tabular}{llll}
\hline & & Antimicrobial resistant determinants \\
\cline { 3 - 4 } Isolates & Species & ESBL genes & $\begin{array}{c}\text { Quinolone } \\
\text { resistant genes }\end{array}$ \\
\hline A33 & E. coli & blacTX-M-14 & \\
A37 & E. coli & & qnrS \\
A63 & E. coli & qnrS \\
B10W & P. penneri & aac6-Ibcr \\
B14W & P. mirabilis & aac6-Ibcr \\
B19W & P. penneri & aac6-Ibcr \\
B43W & P. penneri & aac6-Ibcr \\
B48W & P. mirabilis & aac6-Ibcr \\
B31 & C. sakazakii & blacTX-M-14 & \\
\hline
\end{tabular}

않았다(Table 3).

\section{고 찰}

항균제는 20 세기 중반 이후로 사람이나 동물에서 발생하는 다 양한 세균 감염을 치료하는데 사용되어왔으며 그 결과는 성공적이 었다. 그러나, 항균제 치료를 시작하고 몇 년이 지나면 세균은 그 항 균제에 대한 내성유전자를 획득하거나 변이를 통해 항균제에 내성 을 보여왔다. 항균제의 무분별한 사용으로 세균은 더 많은 항균제 내성유전자를 축적하게 되었을 뿐 아니라 항균제 내성유전자의 수 평 및 수직확산 통해 다제내성을 획득하게 되었다. 이렇게 출현한 다제내성 세균은 병원뿐만 아니라 지역사회 및 축사환경에 널리 퍼 지게 되었다[2]. 본 연구에서는 축사환경에 다제내성 세균의 출현 및 전파양상을 숙고하고 확산 방지책을 마련하는데 필요한 기초자 료를 제공하고자 경북지역의 축사환경에 존재하는 장내세균을 대 상으로 항균제 내성양상 및 항균제 내성유전자를 조사하였다.

본 연구에서 분리된 총 43 균주의 장내세균을 대상으로 항균제 감수성 검사를 실시한 결과 cefepime, ceftazidime, 및 cefaclor를 제외한 amikacin, ampicillin, cephalothin, cefotaxime, ciprofloxacin, gentamicin, kanamycin, levofloxacin, nalidixic acid, spectinomycin, 및 streptomycin에 높은 내성을 나타냈다. 특히 E. coli의 경우 건강한 사람에서 분리된 E. coli의 ampicillin, kanamycin, streptomycin, 및 ciprofloxacin에 대한 항균제 내성 율이 $1.2 \%$ 부터 $36.5 \%$ 까지 분포하는데[13] 비해 본 연구에서 분리 된 대장균의 동일한 항균제에 대한 내성율은 $75.0 \%$ 부터 $84.4 \%$ 까 지 분포하였다(Table 2). 즉 건강한 사람에서 분리된 대장균보다축 사환경에서 사육된 닭으로부터 분리된 대장균의 내성률이 월등하 게 높은 것을 본 연구에서 확인할 수 있었다.

장내세균 43균주를 대상으로 플라스미드를 통해 전파될 수 있
는 항균제 내성유전자를 검출한 결과 총 2균주가 $\beta$-lactam 계열 항 균제에 내성을 나타내는 대표적인 ESBL 유전자인 blacTX-M-14을 가 지고 있음을 확인하였다. 최근 국내에서 분리되는 대장균에서 가장 유행하는 ESBL형은 CTX-M형으로 특히 CTX-M-14형과 CTX-M-15형의 빈도가 높다고 보고되고 있다[14]. CTX-M-14형 유전자를 포함하는 균주는 cefotaxime에 대한 내성율이 매우 높은 것으로 알려져 있는데[15] 본 연구에서도 blacTX-M-14을 가지고 있 는 2 균주 모두 cefotaxime에 내성을 보였다. CTX-M-14형 ESBL 은 사람에 존재하는 장내세균에서는 흔하게 검출되지만 가축의 장 내세균에서는 보고된 바가 드물다. 특히 경북지역의 닭으로부터 분 리된 장내세균에서 CTX-M-14형 ESBL이 검출된 것은 이번이 처 음이다.

한편 quinolone 내성유전자인 $q n r S$ 와 $a a d\left(6^{\prime}\right)-I b-c r$ 유전자가 각각 2균주와 5균주에서 확인되었다. Quinolone 계열 항균제에 내성을 나타내는 장내세균은 세계 여러나라에서 보고되고 있으며 다제내성을 나타내는 경우가 많아 문제가 되고 있다[16]. 특히 $q n r$ 유전자는 플라스미드를 통해 전파되는데 quinolone으로부터 DNA gyrase를 보호하는 단백을 암호화한다[16]. Aac(6')-Ib-cr 은 aminoglycoside acetyltransferase가 변이된 것으로 quinolone계열 항균제를 변형시켜 항균제가 세균에 작용하지 못 하게 한다. $q n r r^{5}$ 와 $a a c\left(6^{\prime}\right)-I b-c r$ 유전자들은 사람으로부터 분리 된 장내세균에서는 보고가 많이 되고 있으나 가금류로부터 분리된 장내세균에서는 보고가 드물며 국내에서는 보고된 바 없다 [17-19]. 경북지역의 닭으로부터 분리된 장내세균에서 $q n r s$ 와 $a a c\left(6^{\prime}\right)-I b-c r$ 유전자가 검출된 것은 이번이 처음이다.

본 연구결과 경북지역의 닭으로부터 분리된 장내세균들은 $\beta$-lactam, quinolone, 및 aminoglycoside계열 항균제에 대한 다 양한 내성유전자를 포함하고 있는 것으로 나타났다. 이들 내성유전 자들은 플라스미드를 통해 다른 세균으로 전파 될 수 있는데 다양 한 내성유전자를 전달받은 세균은 다제내성을 보여 항균제 치료를 어렵게 만들 수 있다. 따라서 다제내성 세균의 출현 및 확산을 방지 하기 위해서는 가축을 대상으로 한 지속적인 항균제 내성유전자에 대한 조사와 감시가 필요할 것으로 사료된다.

\section{요 약}

지난 반세기 동안 세균 감염증 치료 또는 성장촉진을 목적으로 가금류에게 광범위하게 항균제를 사용해 왔다. 그러나 항균제 내성 의 증가는 사람에게 보편적으로 사용되는 항균제들에 대한 내성을 유도하여 치료를 위한 항균제 선택에 제약을 주어 치료에 어려움을 가중시키고 있다. 본 연구에서는 경상도 지역에서 사육된 닭으로부 
터 분리된 장내세균을 대상으로 $\beta$-lactam, quinolone, 및 aminoglycoside 계열 항균제에 대한 내성유전자의 빈도를 조사하 였다. 그리고 항균제 감수성 검사를 시행하여 내성유전자와의 관련 성을 알아보았다. 본 연구에서 총 43 균주의 장내세균이 40 마리의 닭의 맹장으로부터 분리되었으며 디스크확산법을 이용하여 항균 제 감수성 검사를 시행하였다. 그리고 중합효소연쇄반응과 염기서 열분석을 통해 플라스미드 매개 항균제 내성 유전자를 조사하였다. 총 43균주 중 2균주가 blactx-M-14 유전자를 포함하고 있었으며 $q n r S$ 및 $\left.a a d 6^{\prime}\right)-I b-c r$ 유전자도 각각 2균주와 5균주에서 확인되 었다. 총 43 균주를 대상으로 항균제 감수성을 조사한 결과 cefepime, ceftazidime, 및 cefaclor를 제외한 모든 항균제에 대해 $0.0 \%$ 부터 $23.3 \%$ 까지의 낮은 감수성률을 보였다. 본 연구에서는 닭으로부터 분리된 대장균에 플라스미드 매개 항균제 내성유전자 가 확산되어 있음을 확인하였다. 항균제 내성 유전자의 확산을 막 기 위해서는 지속적인 항균제 내성유전자의 조사와 감시가 필요할 것으로 사료된다.

\section{Acknowledgements: None}

Funding: None

Conflict of interest: None

\section{References}

1. Lee K, Lim JB, Yum JH, Yong D, Chong Y, Kim JM, et al. blavim-2 cassette-containing novel integrons in metallo- $\beta$-lactamase-producing Pseudomonas aeruginosa and Pseudomonas putida isolates disseminated in a Korean hospital. Antimicrob Agents Chemother. 2002;46:1053-1058.

2. Lee K, Yum JH, Yong D, Lee HM, Kim HD, Docquier JD, et al. Novel acquired metallo- $\beta$-lactamase gene, bla(SIM-1) in a class 1 integron from Acinetobacter baumannii clinical isolates from Korea. Antimicrob Agents Chemother. 2005;49:4485-4491.

3. Kwon YI, Kim TW, Kim HY, Chang YH, Kwak HS, Woo GJ, et al. Monitoring of antimicrobial resistant bacteria from animal farm environments in Korea. Kor J Microbiol Biotechnol. 2007; 1:17-25.

4. Rubin JE, Pitout JDD. Extended-spectrum $\beta$-lactamase, carbapenemase and AmpC producing Enterobacteriaceae in companion animals. Vet Microbiol. 2014;170:10-18.

5. Kim MH, Lee HJ, Park KS, Suh JT. Molecular characteristics of extended spectrum beta-lactamases in Escherichia coli and Klebsiella pneumoniae and the prevalence of $q n r$ in extended spectrum beta-lactamase isolates in a tertiary care hospital in Korea. Yonsei Med J. 2010;51:768-774.

6. Park SD, Uh Y, Lee G, Lim K, Kim JB, Jeong SH. Prevalence and resistance patterns of extended-spectrum and AmpC $\beta$-lactamase in Escherichia coli, Klebsiella pneumoniae, Proteus mirabilis, and Salmonella serovar Stanley in a Korean tertiary hospital. APMIS. 2010;118:801-808.
7. Seo MR, Park YS, Pai H. Characteristics of plasmid mediated quinolone resistance genes in extended-spectrum cephalosporin-resistant isolates of Klebsiella pneumoniae and Escherichia coli in Korea. Chemotherapy. 2010;56:46-53.

8. CLSI. Performance standards for antimicrobial susceptibility testing; 16th informational supplement. CLSI document M100S20. Wayne, PA: Clinical and Laboratory Standards Institute;2010, p52-53.

9. Lewis JS, Herrera M, Wickes B, Patterson JE, Jorgensen JH. First report of the emergence of CTX-M-type extended-spectrum beta-lactamases (ESBLs) as the predominant ESBL isolated in a U.S. health care system. Antimicrob Agents Chemother. 2007; 51:4015-4021.

10. Hidalgo L, Hopkins KL, Gutierrez B, Ovejero CM, Shukla S, Douthwaite $S$, et al. Association of the novel aminoglycoside resistance determinant $\mathrm{RmtF}$ with NDM carbapenemase in Enterobacteriaceae isolated in India and the UK. J Antimicrob Chemother. 2013;68:1543-1550.

11. Cattoir V, Poirel L, Rotimi V, Soussy CJ, Nordmann P. Multiplex PCR for detection of plasmid-mediated quinolone resistance $q n r$ genes in ESBL-producing enterobacterial isolates. J Antimicrob Chemother. 2007;60:394-397.

12. Song S, Lee EY, Koh EM, Ha HS, Jeong HJ, Bae IK, et al. Antibiotic resistance mechanisms of Escherichia coli isolates from urinary specimens. Korean J Lab Med. 2009;29:17-24.

13. Kang HY, Jeong YS, Oh JY, Tae SH, Choi CH, Moon DC, et al. Characterization of antimicrobial resistance and class 1 integrons found in Escherichia coli isolates from humans and animals in Korea. J Antimicrobial Chemother. 2005;55:639-644.

14. Park Y, Kang HK, Bae IK, Kim J, Kim JS, Uh Y, et al. Prevalence of the extended-spectrum $\beta$-lactamase and qnr genes in clinical isolates of Escherichia coli. Korean J Lab Med. 2009; 29:218-223.

15. Song W, Lee H, Lee K, Jeong SH, Bae IK, Kim JS, et al. CTX-M-14 and CTX-M-15 enzymes are the dominant type of extended-spectrum $\beta$-lactamase in clinical isolates of Escherichia coli from Korea. J Med Microbiol. 2009;58:261266.

16. Lautenbach E, Strom BL, Nachamkin I, Bilker WB, Marr AM, Larosa LA, et al. Longitudinal trends in fluoroquinolone resistance among Enterobacteriacae isolates from inpatients and outpatients, 1989-2000: differences in the emergence and epidemiology of resistance across organisms. Clin Infect Dis. 2004;38:655-662.

17. Kim S, Sung JY, Cho HH, Kwon KC, Koo SH. Characterization of CTX-M-14- and CTX-M-15-Producing Escherichia coli and Klebsiella pneumoniae Isolates from Urine Specimens in a Tertiary-Care Hospital. J Microbiol Biotechnol. 2014;24:765770.

18. Kim JH, Cho JK, Kim KS. Prevalence and characterization of plasmid-mediated quinolone resistance genes in Salmonella isolated from poultry in Korea. Avian Pathol. 2013;42(3): 221-229.

19. Yang BS. Multiplex PCR for detection of quinolone resistance $q n r$ genes in extended-spectrum $\beta$-lactamase producing Escherichia coli and Klebsiella pneumoniae. Korean J Clin Lab Scil. 2007;39:161-166. 